\title{
Variations in oil palm (Elaeis guineensis Jacq.) progeny response to high aluminium concentrations in solution culture
}

\begin{abstract}
Aluminium (Al) phytotoxicity is an important soil constraint that limits crop yield. The objectives of this study were to investigate how growth, physiology, nutrient content and organic acid concentration is affected by $\mathrm{Al}$, and to assess the degree of $\mathrm{Al}$ tolerance in different oil palm progeny (OPP). Four OPPs ['A' (Angola dura $\times$ Angola dura), 'B' (Nigerian dura $\times$ Nigerian dura), ' $C$ ' (Deli dura $\times$ AVROS pisifera) and ' $D$ ' (Deli dura $\times$ Dumpy AVROS pisifera)] were grown in different Al concentrations $(0,100$ and $200 \mu \mathrm{m})$ in aerated Hoagland solution, $\mathrm{pH} 4.4$, for 80 days. We observed a severe reduction $(57.5 \%)$ in shoot dry weight, and root tips were reduced by $46.5 \%$ in $200 \mu \mathrm{m} \mathrm{Al}$. In 'B' and ' $\mathrm{C}$ ', the majority of macro- and micronutrients in plants were reduced significantly by $200 \mu \mathrm{m} \mathrm{Al}$, with $\mathrm{Mg}$ being lowered by more than $50 \%$ in roots and shoots. The $200 \mu \mathrm{m} \mathrm{Al}$ treatment resulted in a $56.50 \%$ reduction in total leaf area, a $20 \%$ reduction in net photosynthesis and a $17 \%$ reduction in SPAD chlorophyll value in the third leaf. Root tips $(0-5 \mathrm{~mm})$ showed a significant increase in oxalic acid content with increasing Al concentration ( 5.86-fold); progeny ' $A$ ' had the highest concentration of oxalic acid. There was a significant interaction between $\mathrm{Al}$ concentration $\times \mathrm{OPP}$ on total leaf number, root volume, lateral root length, $\mathrm{Mg}$ and $\mathrm{K}$ in root and shoot tissues, and $\mathrm{Ca}$ and $\mathrm{N}$ in shoots. The OPPs could be ranked in their tolerance to $\mathrm{Al}$ as: ' $\mathrm{A}$ ' > 'D' > ' $\mathrm{B}$ ' > ' $\mathrm{C}$ '.
\end{abstract}

Keyword: Elaeis guineensis, oxalic acid, photosynthesis, SPAD chlorophyll value 